\title{
POPULATION DENSITIES AND GENETIC DIVERSITY OF ACTINOMYCETES ASSOCIATED TO THE RHIZOSPHERE OF THEOBROMA CACAO
}

\author{
Tâmara R. Barreto; Augusto C.M. da Silva; Ana Cristina F. Soares; Jorge T. de Souza* \\ Universidade Federal do Recôncavo da Bahia, Campus Universitário de Cruz das Almas, Cruz das Almas, BA, Brasil \\ Submitted: January 11, 2008; Returned to authors for corrections: March 15, 2008; Approved: May 04, 2008.
}

\begin{abstract}
In spite of the acknowledged importance of growth-promoting bacteria, only a reduced number of studies were conducted with these microorganisms on Theobroma cacao. The objectives of this work were to study the population densities and genetic diversity of actinomycetes associated with the rhizosphere of cacao as a first step in their application in plant growth promotion and biological control. The populations densities of actinomycetes in soil and cacao roots were similar, with mean values of $1,0 \times 10^{6} \mathrm{CFU} / \mathrm{g}$ and $9,6 \times 10^{5} \mathrm{CFU} / \mathrm{g}$, respectively. All isolates selected and used in this study were identified through sequencing analyses of a fragment of the $r p o \mathrm{~B}$ gene that encodes the $\beta$-subunit of the RNA polymerase as species of the genus Streptomyces. In vitro cellulolytic, xilanolytic and chitinolytic activity, indolacetic acid production and phosphate solubilization activities were observed in most of the isolates tested. The data obtained in this study demonstrate that actinomycetes account for a higher percentage of the total population of culturable bacteria in soil than on cacao roots. Additionally, actinomycetes from the cacao rhizosphere are genetically diverse and have potential applications as agents of growth promotion.
\end{abstract}

Key-words: cacao, rpoB sequence analyses, Streptomyces spp.

\section{INTRODUCTION}

Chocolate is made of dried seeds obtained from the cacao tree (Theobroma cacao, Malvaceae). This crop is cultivated mainly by smallholder farmers in the humid tropical areas of the world, including South and Central America, Asia and Africa (28). The main constraint for cacao production around the world is the occurrence of diseases caused by fungi, Stramenopila and viruses $(3,11)$. These diseases are not properly managed in most farms because of several reasons, among them, the lack of knowledge and alternatives and the high costs of labor and agrochemicals. Novel alternatives for controlling cacao diseases are required and many researchers around the world are looking at different possibilities. Biological control is one the most desired methods for controlling cacao diseases due to its environmentally-friendly characteristics and lower costs as compared to chemicals. Several microorganisms are being investigated for their potential as biological control agents of cacao diseases. Trichoderma stromaticum, a mycoparasite that destroys Moniliophthora perniciosa, the agent of witches' broom disease, is being used in the field (30). Although very efficient as a mycoparasite, this fungus does not prevent the infection of cacao trees by the pathogen. Other microorganisms that may give protection against pathogen invasion include fungal endophytes, other mycoparasitic fungi, rhizobacteria and actinomycetes (22). Endophytes from leaves and trunks of cacao and other mycoparasites are being studied by some groups $(2,13)$. On the other hand, little is known about the microorganisms associated to the cacao rhizosphere, specially the actinomycetes.

Actinomicetes are Gram positive, aerobic and myceliumforming bacteria. This group of prokaryotes is known for their activity in nutrient cycling, nitrogen fixation, production of secondary metabolites and plant-growth promotion $(7,20)$. Plant-growth promotion may occur due to both direct and indirect effects. Direct effects include production of

*Corresponding Author. Mailing address: Universidade Federal do Recôncavo da Bahia, Campus Universitário de Cruz das Almas, CEP 44380-000 Cruz das Almas, BA. E-mail: jorge@ufrb.edu.br 
phytohormones, phosphate solubilization, nitrogen fixation and increased nutrient uptake. While indirect effects may be due to the control of pathogens by the production of secondary metabolites, competition, parasitism and induction of resistance (7). Although some information is available on the populations of actinomycetes in a range of soils and plant roots $(8,10)$, virtually nothing is known about the population densities of these bacteria on the cacao rhizosphere and their influence on plant growth and health. The most commom genus among this large group of bacteria is Streptomyces, with more than 3000 species (6). This genus is found worldwide and is thought to play an important role in soil and plant ecology. These organisms have been widely investigated as agents of biological control of several plant diseases (16). However, despite the recognized importance of these microbes, no studies so far have addressed the role of root-associated actinomycetes in plant growth promotion and biological control of cacao diseases. In one study, actinomycetes isolated from the surface of cacao pods showed great potential in the biological control of black pod rot and witches' broom disease (22).

This research aimed at studying the population densities and the diversity of actinomycetes associated to the cacao rhizosphere as a first step in the application of these microorganisms in growth promotion and management of cacao diseases. Population densities of actinomycetes were determined in soil and roots of cacao trees. Sequencing analyses of a fragment of the $r p o \mathrm{~B}$ gene, encoding the $\beta$-subunit of RNA polymerase, allowed the study of the genetic diversity and the molecular identification of representative isolates. Production of extracellular enzymes was evaluated to access the potential use of these microorganisms in biological control of cacao diseases.

\section{MATERIALAND METHODS}

\section{Population densities and isolation of actinomycetes from soil and root samples}

Four samples of soil and cacao roots were collected in December 2006. Each sample was composed of six sub-samples.
Samples 1.A and 1.B were obtained from four year-old field plantations established at CEPLAC/CEPEC (Centro de Pesquisas do Cacau) and samples 2.A and 2.B from IBC (Instituto Biofábrica de Cacau), a facility used to produce cloned cacao cuttings, both institutions are located in the municipality of Ilhéus, Bahia State. Physical and chemical characteristics of the soil samples used in this study are listed in Table 1.

Population densities on roots and soil were determined by dilution plating onto nutrient agar (21) for total culturable bacteria and onto soil extract medium (22) for actinomycetes. Both media were amended with ciclohexamide $(100 \mu \mathrm{g} / \mathrm{mL})$ and culturable bacteria were determined after incubating at $25^{\circ} \mathrm{C}$ for $48 \mathrm{~h}$ and actinomycetes after incubation at $30^{\circ} \mathrm{C}$ for 12 days. Discrete actinomycete colonies were randomly selected, transferred to AGS medium (Arginine-Glycerol-Mineral Salt Agar) (25), grown at $30^{\circ} \mathrm{C}$ for 14 days, stored at $-20^{\circ} \mathrm{C}$ in $40 \%$ glycerol to be used in further studies.

Quantification of the population densities was done twice, data were transformed with $\log (\mathrm{x}+1)$, where $\mathrm{x}$ is the number of $\mathrm{CFU} / \mathrm{g}$ soil or roots. Statistical analyses were performed separately for each experiment with the program SAS (SAS institute, Inc.). Tukey's test at $5 \%$ probability was used to test the differences among the means.

\section{Genetic diversity and molecular identification of actinomycetes}

A total of 38 actinomycete isolates were randomly selected and used in the genetic diversity and molecular identification studies by sequencing of a fragment of the rpoB gene.

For DNA extraction, the actinomycete isolates were grown for 20 days in liquid starch-casein medium (19). Cells were collected by centrifuging the growth medium at $14,000 \mathrm{rpm}$ for $15 \mathrm{~min}$. The collected cells were lyophilized for $18 \mathrm{~h}$ and ground with liquid nitrogen. Approximately $20 \mathrm{mg}$ of the powder was used for extraction following the glass powder protocol (26).

For theses studies, sequencing analyses of the rpoB gene was used, following recommendations of Kim et al. (17). According to these authors, $r p o \mathrm{~B}$ sequencing proved superior to sequences of the $16 \mathrm{~S}$ region of the rDNA for phylogenetic

Table 1. Physicochemical characteristics of the soils used in this study.

\begin{tabular}{|c|c|c|c|c|c|c|c|c|c|c|c|c|c|c|}
\hline \multirow[t]{2}{*}{ Sample } & \multirow[t]{2}{*}{$\mathrm{pH}^{\mathrm{a}}$} & \multicolumn{4}{|c|}{$\left(\mathrm{cmol}_{\mathrm{c}} / \mathrm{dm}^{3}\right)^{\mathrm{b}}$} & \multirow{2}{*}{$\frac{\left(\mathrm{g} / \mathrm{dm}^{3}\right)}{\mathrm{C}}$} & \multicolumn{5}{|c|}{$\left(\mathrm{mg} / \mathrm{dm}^{3}\right)$} & \multicolumn{3}{|c|}{ Content (\%) } \\
\hline & & $\mathrm{Al}$ & $\mathrm{Ca}$ & $\mathrm{Mg}$ & $\mathrm{K}$ & & $\mathrm{P}$ & $\mathrm{Fe}$ & $\mathrm{Zn}$ & $\mathrm{Cu}$ & $\mathrm{Mn}$ & Sand & Silt & Clay \\
\hline 1.A & 5.4 & 0.0 & 13.2 & 4.0 & 17.2 & 25.2 & 17 & 93 & 29 & 18 & 206 & 38.1 & 44.8 & 17.1 \\
\hline 1.B & 5.5 & 0.0 & 14.9 & 3.9 & 18.8 & 39.5 & 20 & 30 & 27 & 129 & 185 & 33.3 & 51.1 & 15.6 \\
\hline 2.A & 4.8 & 0.8 & 4.4 & 1.6 & 6.0 & 18.2 & 115 & 73 & 6 & 6 & 63 & 56.9 & 21.2 & 21.9 \\
\hline $2 . B$ & 4.9 & 1.2 & 4.2 & 1.0 & 5.2 & 21.4 & 184 & 87 & 5 & 25 & 31 & 55.9 & 22.1 & 22.0 \\
\hline
\end{tabular}

${ }^{\mathrm{a}} \mathrm{pH}$ determined in water; ${ }^{\mathrm{b}} \mathrm{Cation}$ exchange capacity. 
analyses and molecular identification of actinomycetes. Sequences of the rDNA possess intrinsic characteristics that render it with limited power to distinguish closely related organisms $(9,33,35)$.

Amplification of a fragment of the rpoB gene, which is the gene that encodes the beta subunit of the DNA-dependent RNA polymerase was amplified with primers SRPOF1 and SRPOR1 (17). PCR was performed in a total volume of $50 \mu \mathrm{L}$ containing 50

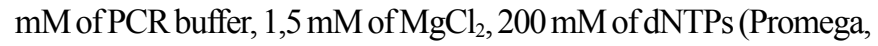
Madison, WI, USA), 20 pmol of each primer, $6 \mu \mathrm{L}$ of genomic DNA (10 ng $\left.\mu \mathrm{L}^{-1}\right)$ and $2 \mathrm{U}$ of Taq DNA polymerase (Promega). The cycling program consisted of an initial denaturation at $94^{\circ} \mathrm{C}$ for $2 \mathrm{~min}, 10$ cycles of denaturation at $94^{\circ} \mathrm{C}$ for $1 \mathrm{~min}$, primer annealing at $58^{\circ} \mathrm{C}$ for $45 \mathrm{sec}$, decreased by $1^{\circ} \mathrm{C}$ each succeeding cycle, and elongation at $72^{\circ} \mathrm{C}$ for $1 \mathrm{~min}$, followed by 30 cycles of denaturation at $94^{\circ} \mathrm{C}$ for $45 \mathrm{sec}$, annealing at $52^{\circ} \mathrm{C}$ for $45 \mathrm{sec}$, elongation at $72^{\circ} \mathrm{C}$ for $1 \mathrm{~min}$, and a final extension of $72^{\circ} \mathrm{C}$ for 5 $\mathrm{min}$. The amplified products were separated on $1.5 \%$ low-melting point agarose gels, excised, frozen for $30 \mathrm{~min}$ at $-80^{\circ} \mathrm{C}$, and centrifuged for $10 \mathrm{~min}$ at $14000 \mathrm{rpm}$ (Eppendorf microcentrifuge) (29). The supernatant was used in sequencing reactions with the Taq-mediated DyeDeoxy terminator cycle sequencing kit (Applied Biosystems, Warrington, UK) in an ABI 3100 genetic analyser (Applied Biosystems, FosterCity, CA) according to the manufacturer's instructions (Applied Biosystems). Forward and reverse sequences were linked in BioEdit version 5.0.9 (12). Sequences obtained for the rpoB fragment were deposited in EMBL (European Molecular Biology Laboratory) under the following accession numbers: AM920540 (isolate 9), AM920505 (11),AM920507 (28),AM920509(30),AM920510(31),AM920511 (32),AM920512(34),AM920513(35),AM920514(36),AM920515 (37),AM920516(38),AM920517(39),AM920518(40),AM920519 (41),AM920520 (42),AM920521 (43),AM920522 (45),AM920523 (46),AM920524(47),AM920525(48),AM920526(49),AM920527 (50),AM920528 (52),AM920529 (53),AM920530(54),AM920531 (56),AM920532 (57),AM920533 (58),AM920534(59),AM920535 (60),AM920536(61),AM920537 (62),AM920541 (65),AM920538 (66), AM920539 (95), AM920504 (103), AM920506 (260), and AM920508 (290).

The following accession numbers were obtained from public databases for comparison purposes: Streptomyces coelicolor (AY280745 and AL939121), S. albiflavus (DQ978980), S. netropsis (AY280782), S. fradiae (AY280750), S. purpureus (AY280795), S. setonii (AY280766), S. violaceusniger (DQ242003 and DQ241994) and Micromonosporae echinospora (AY280788).

Alignments were done with ClustalX version 1.8 (31). The BLAST program (1) was used to compare the sequences with the ones deposited in public databases. Phylogenetic trees were constructed with the program MEGA version 3.1 (18) with the method of maximum parsimony with parameters of Jukes-Cantor and bootstrap analysis with 1000 resamplings.

\section{Production of extracellular enzymes, indolacetic acid, and} phosphate solubilization

The following 26 isolates were randomly selected and tested for production of extracellular enzymes, phosphate solubilization and production of indolacetic acid: $32,35,36,37,38,39,40,41$, $42,46,47,48,49,51,52,53,54,55,56,57,58,59,61,63,65$, and 66 . All isolates, with the exception of 51,55 and 63 , were identified by $r p o \mathrm{~B}$ sequencing analyses.

Secretion of the extracellular enzymes cellulase, chitinase and xylanase were determined by cultivating the isolates on a minimal salts medium (32), supplemented with crystalline cellulose (Vetec), xylan (Sigma) and colloidal chitin (Sigma), respectively as sole carbon source (27). Phosphate solubilization capacity was determined by growing the isolates on Tryptic Casein Soybean Agar (TSA) supplemented with $\mathrm{CaHPO}_{4}$ (14). Indolacetic acid production was tested by growth on TSA medium amended with $5 \mathrm{mM}$ of L-tryptophan according to the method described by Brici et al. (4).

\section{RESULTS}

\section{Population densities}

Population densities of total culturable bacteria were not significantly different in soil and cacao roots $(P>0.05)$. Actinomycete population densities were also similar in soil and roots $(P>0.05)$ (Table 2). However, when populations of total culturable bacteria were compared to actinomycete populations separately, in soil and on cacao roots, there were significant differences for both $(P<0.05$; data not shown). The percentage of the total culturable bacterial population represented by actinomycetes varied from 0.3 to $5.2 \%$ in soil and from 0.02 to $2.4 \%$ on cacao roots (Table 2 ). These data show that populations of actinomycetes although similar in soil and on roots accounted for a higher percentage of the populations of total culturable bacteria in soil than on roots.

\section{Genetic diversity and molecular identification}

A total of 38 actinomycete isolates from the cacao rhizosphere were randomly selected for sequencing a fragment of the $r p o \mathrm{~B}$ gene. This gene encodes the $\beta$-subunit of RNA polymerase. Phylogenetic analysis of 307-bp aligned nucleotides showed that these isolates are genetically diverse and belong to the genus Streptomyces (Fig. 1).

Five genetic groups were formed among the 38 isolates included in the study (Fig. 1). The 25 isolates included in genetic group I showed sequence identities varying from 93 to $100 \%$. Isolates from this genetic group showed 95.3 to $100 \%$ sequence identity when compared their most closely related sequences in the database, which are from Streptomyces coelicolor isolates (accession numbers AY280745 and AL939121). The 6 isolates from genetic group II showed sequence identities varying from 95 to $100 \%$ among them. Sequence identity was $99.7 \%$ when 


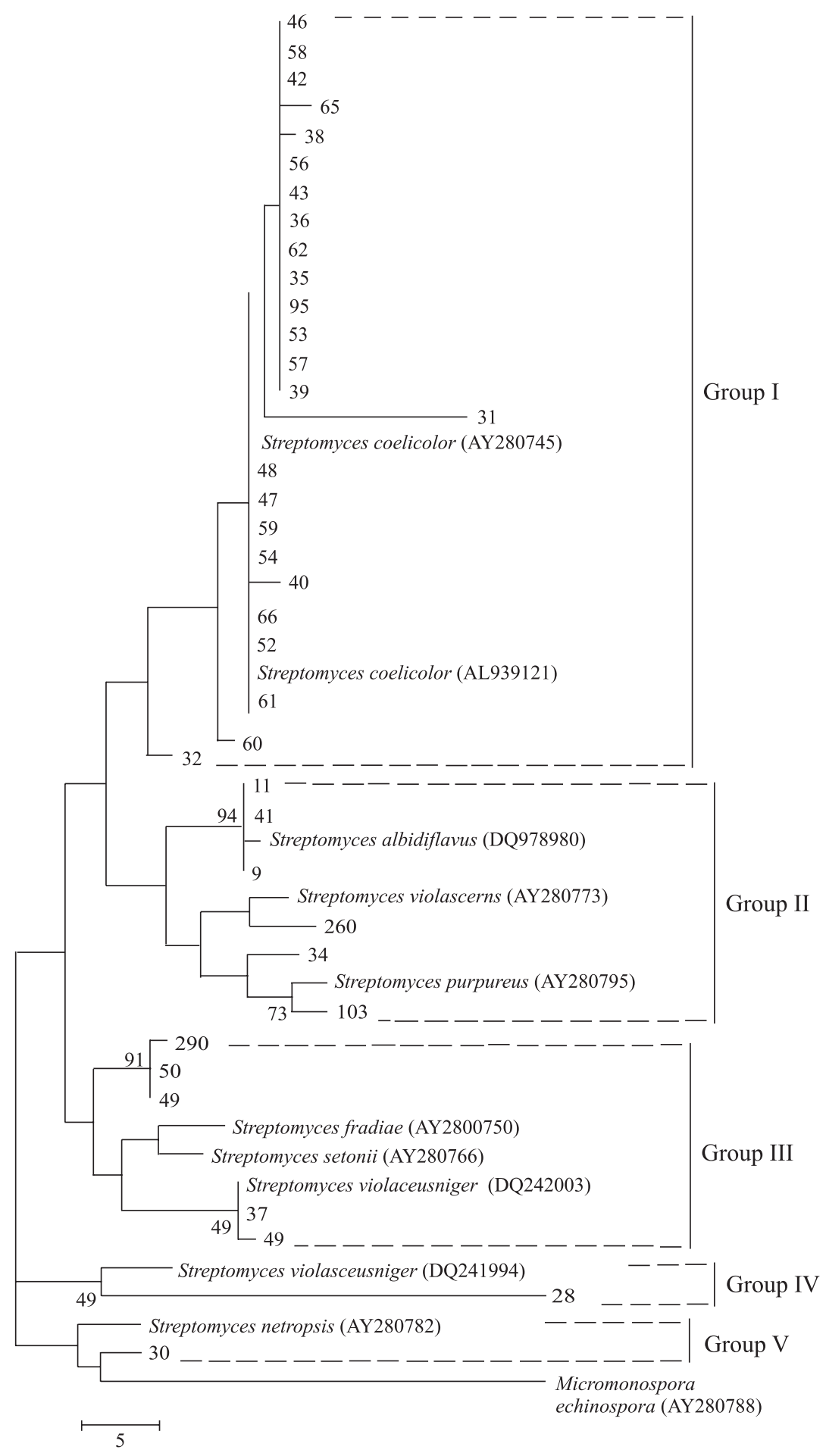

Figure 1. Phylogenetic tree of selected actinomycete isolates from the rhizosphere of Theobroma cacao based on 315-bp of aligned nucleotides from a fragment of the gene rpoB. The tree was inferred with the Maximum Parcimony method with parameters of Jukes-Cantor. Bootstrap values higher than $70 \%$ are shown at the appropriate branching points. The scale indicates the number of nucleotide substitutions per site. isolates 9,11 , and 41 were compared to a sequence of the same gene obtained from the species S. albidiflavus DQ978980 deposited in public databases. Isolate 260 had an identity of $98 \%$ when compared to $S$. violascens AY280773. Isolates 34 and 103 showed sequence identities of 97.3 and $98.7 \%$ respectively when compared to their most closely related species, $S$. purpureus AY280795. In genetic group III, the 5 isolates had identities varying from 95 to $100 \%$ among them. Isolates 49, 50, and 290 showed identities varying from 97.3 to $97.6 \%$ when compared to their most closely related species, S. fradiae AY280750 and S. setonii AY280766. Isolates 37 and 45 had 100 and $99.7 \%$ sequence identity when compared to $S$. violasceusniger DQ242003. Isolate 28, the only component of genetic group IV is most closely related to $S$. violasceusniger DQ241994, with 88.9\% sequence identity between them. In genetic group $\mathrm{V}$, its only component, isolate 30 , showed $89.6 \%$ sequence identity when compared to its most closely related species, $S$. netropsis AY280782.

\section{Production of extracellular enzymes, indolacetic acid, and phosphate solubilization}

From the 26 isolates tested, all of them were capable of producing cellulase, $92.3 \%$ produced xylanase, $84.6 \%$ produced chitinase, $88.5 \%$ secreted indolacetic acid and $84.6 \%$ were able to solubilize phosphate.

\section{DISCUSSION}

Despite the acknowledged importance of soil and root associated microorganisms, little is known about and the effects of actinomycetes associated with Theobroma cacao. In this study we focused on the population densities and genetic diversity of actinomycetes from the cacao rhizosphere as a first step toward a practical application of these microbes as agents of biological control and plant-growth promotion.

The fact that populations of actinomycetes accounted for a higher percentage of the total culturable bacteria in soil than on roots is probably due to the low competitive capacity of this group of bacteria on roots (24). Other studies show that populations of actinomycetes represent more than $30 \%$ of the total culturable bacteria from soils and roots $(15,23)$. However, 
Table 2. Population densities of culturable bacteria and actinomycetes associated with the cacao rhizosphere

\begin{tabular}{|c|c|c|c|c|c|c|}
\hline \multirow[t]{2}{*}{ Sample } & \multicolumn{2}{|c|}{$\begin{array}{c}\text { Total culturable bacteria } \\
\text { CFU/g soil }\end{array}$} & \multicolumn{2}{|c|}{$\begin{array}{c}\text { Actinomycetes } \\
\text { CFU/g soil }\end{array}$} & \multicolumn{2}{|c|}{$\begin{array}{c}\text { Actinomicetes/Culturable } \\
\text { bacteria }(\%)^{\mathrm{c}}\end{array}$} \\
\hline & Soil $^{b}$ & Roots & Soil & Roots & Soil & Roots \\
\hline 1.B & $1,53 \times 10^{8} a$ & $1,21 \times 10^{9} \mathrm{a}$ & $5,3 \times 10^{5} \mathrm{a}$ & $2,1 \times 10^{5} \mathrm{a}$ & 0,34 & 0,02 \\
\hline 2.A & $1,90 \times 10^{8} \mathrm{a}$ & $8,23 \times 10^{8} \mathrm{a}$ & $5,6 \times 10^{5} \mathrm{a}$ & $8,2 \times 10^{5} \mathrm{a}$ & 0,30 & 0,10 \\
\hline
\end{tabular}

${ }^{a}$ Mean values of three replicates are shown; ${ }^{b}$ Mean values followed by the same letter in the rows (comparing soil and roots in the same sample) are not significantly different according to Tukey's studentized range test $(P=0.05)$; ${ }^{\mathrm{c}}$ Percentage of actinomycetes in relation to total culturable bacteria.

our studies showed that actinomycetes accounted for a maximum of 5 and $2.5 \%$ of the total culturable bacteria in soil and roots, respectively (Table 2). These results may indicate that actinomycetes do not favor the association with the rhizosphere of Theobroma cacao, although we recognize that a limited number of samples was analyzed. Analyses of a higher number of samples should be performed to confirm this hypothesis.

The molecular identification of 38 isolates was accomplished by sequencing analyses of a fragment of the gene rpo $\mathrm{B}$ that encodes the $\beta$-subunit of RNA polymerase (Fig. 1). The identification of all selected isolates as species of the genus Streptomyces was somewhat expected because this genus represents $70-90 \%$ of the actinomycetes found in natural environments $(15,23)$.

Actinomycete taxonomy is in a stagnant phase where although there are more than 3000 species described (6), no scientific study has looked at the number of valid species in an integrated manner. The inexistence of a complete culture collection containing all described actinomycete species is the most limiting factor for accomplishing this task. In this study, 25 out of 38 isolates were identified as $S$. coelicolor (Fig. 1). The variation of sequence identity among the isolates and the reference strains does not allow a precise identification of all isolates in group I and in the other genetic groups. Some of the isolates used in this study may represent undescribed species since the diversity of actinomycetes associated with cacao cultivated in Brazilian soils is largely untapped. Obviously, further taxonomic studies should be conducted in a worldwide context in order to gain more insight in the taxonomy of actinomycetes in general and in the genus Streptomyces in particular. Detailed studies should be performed on the basis of a multigene sequence approach to allow an in-depth phylogenetic assessment of the diversity within the actinomycetes associated with Theobroma cacao.

The ability of most actinomycete isolates tested to produce extracellular enzymes, indolacetic acid and their capacity to solubilize phosphate in our in vitro experiments seems not to be responsible for the induction of plant growth observed in greenhouse assays. In these preliminary experiments, two out of 13 isolates tested in a repeated experiment were able to significantly $(P<0.05)$ increase shoot length of cacao seedlings grown on substrate treated with these isolates (data not shown). Interestingly, their ability to produce extracellular enzymes, indolacetic acid and to solubilize phosphate did not differ in our in vitro assays. Although we are aware that in general there is no correlation between results of in vitro experiments and in vivo activity $(34,36)$, these in vitro assays may indicate the potential of the isolates being tested for applications such as biological control, composting, and plant-growth promotion, as reported by other authors (5). We are in the process of testing other isolates as agents of plant growth and against cacao diseases as a first step in their field application.

In conclusion, we report the first, if not the only study on population densities and genetic diversity of actinomycetes in the rhizosphere of Theobroma cacao and began addressing their use in growth promotion.

\section{ACKNOWLEDGEMENTS}

The authors thank IFS (International Foundation for Science, Sweeden) and FAPESB (Fundação de Amparo à Pesquisa do Estado da Bahia) for financial support and CNPq for providing fellowships to the first, third and fourth authors.

\section{RESUMO}

\section{Densidades populacionais e diversidade genética de actinomicetos associados a rizosfera de Theobroma cacao}

Apesar da reconhecida importância das bactérias promotoras de crescimento, apenas um reduzido número de estudos foi conduzido com este grupo de microrganismos na cultura do 
cacaueiro. Os objetivos deste trabalho foram o estudo da densidade populacional e da diversidade genética de actinomicetos associados à rizosfera do cacaueiro como o primeiro passo para sua utilização na promoção de crescimento de mudas desta cultura e no controle biológico de doenças. As densidades populacionais de actinomicetos em amostras de solo e de raízes de cacaueiro foram semelhantes, com valores médios de $1,0 \times 10^{6} \mathrm{UFC} / \mathrm{g}$ e de $9,6 \times 10^{5} \mathrm{UFC} / \mathrm{g}$, respectivamente. Todos os isolados selecionados para este estudo foram identificados através de análises de seqüências de um fragmento do gene $r p o \mathrm{~B}$, que codifica a $\beta$-subunidade da RNA polimerase, como pertencentes ao gênero Streptomyces. Dentre os isolados testados, constatou-se in vitro, a produção de celulase, xilanase, quitinase, ácido indolacético e a capacidade de solubilização de fosfato. Os dados obtidos demonstram que os actinomicetos representam uma maior proporção da população total de bactérias cultiváveis em solo do que em raízes. Adicionalmente, os actinomicetos da rizosfera do cacaueiro são geneticamente diversos e apresentam potencial para atuarem como agentes de promoção de crescimento.

Palavras-chave: cacau, análises de seqüências do gene rpoB, Streptomyces spp.

\section{REFERENCES}

1. Altschul, S.F.; Madden, T.L.; Schaffer, A.A.; Zhang, J.; Miller, W.; Lipman, D.J. (1997). Gapped BLAST and PSI-BLAST: a new generation of protein database search programs. Nucleic Acids Res., 25, 3389-3402.

2. Arnold, A.E.; Mejía, L.C.; Kyllo, D.; Rojas, E.I.; Maynard, Z.; Robbins, N.; Herre, E.A. (2003). Fungal endophytes limit pathogen damage in a tropical tree. Proc. Natl. Acad. Sci. USA 100, 1564915654 .

3. Bowers, H.J.; Bayley, B.A.; Hebbar, K.P.; Sanogo, S.; Lumsden, R.D. (2001). The impact of plant diseases on world chocolate production. Plant Health progress._http://www.plantmanagementnetwork.org/ php/default.asp/10.1094/PHP: 0709-01.

4. Brici, J.M.; Bostock, R.M.; Silverstone, S.E. (1991). Rapid in situ assay for indole-acetic acid production by bacteria immobilized on a nitrocellulose membrane. Appl. Environ. Microbiol., 57, 535-538.

5. Cavaglieri, L.R.; Passone, A.; Etcheverry, M.G. (2004). Correlation between screening procedures to select root endophytes for biological control of Fusarium verticillioides in Zea mays L. Biol. Cont., 31, 259-267.

6. Christova, K.; Sholeva, Z.; Chipeva, V. (1995). Application of molecular biological methods in taxonomy of genus Streptomyces. J. Cult. Collect., 1, 3-10.

7. Conn, K.L.; Nowak, J.; Lazarovits, G.A (1997). Gnotobiotic bioassay for studying interactions between potatoes and plant growthpromoting rhizobacteria. Can. J. Microbiol., 43, 801-808.

8. Davelos, A.L.; Kinkel, L.L.; Samac, D.A. (2004). Spatial variation in frequency and intensity of antibiotic interactions among streptomycetes from prairie soil. Appl. Environ. Microbiol., 70, 1051-1058.

9. Fox, G.E.; Wisotzkey, J.D.; Jurtshuk, P.Jr. (1992). How close is close: $16 \mathrm{~S}$ rRNA sequence identity may not be sufficient to guarantee species identity. Int. J. Syst. Bacteriol., 42, 166-170.
10. Gorlach-Lira, K.; Coutinho, H.D.M. (2007). Population dynamics and extracellular enzymes activity of mesophilic and thermophilic bacteria isolated from semi-arid soil of northeastern Brazil. Braz. J. Microbiol., 38, 135-141.

11. Gotsch, N. (1997). Cocoa crop protection: an expert forecast on future progress, research priorities and policy with help of the Delphi survey. Crop Prot., 16, 227-233.

12. Hall, T.A. (1999). BioEdit: a user-friendly biological sequence alignment editor and analysis program for Windows 95/98/NT. Nucleic Acids Res., 41, 95-98.

13. Holmes, K.A.; Schroers, H.J.; Thomas, S.E.; Evans, H.C.; Samuels, G.J. (2004). Taxonomy and biocontrol potential of a new species of Trichoderma from the Amazon basin of South America. Mycol. Progr., 3, 199-210.

14. Katznelson, H.; Bose, B. (1959). Metabolic activity and phosphatedissolving capability of bacterial isolates from wheat roots and rhizosphere soil. Can. J. Microbiol., 5, 79-85.

15. Kennedy, A.C. (1999). Bacterial diversity in agroecosystems. Agr. Ecosyst. Environ., 74, 65-76.

16. Khalad, A.E.; Hardy, G.E.; Sivasithamparam, K.; Hussein, A.M.; Kurtboke, D.I. (1997). The potential for biological control of cavity-spot disease of carrots, caused by Pythium coloratum, by streptomycete and nonstreptomycete actinomycetes. New Phytol., 137, 495-507.

17. Kim, B.J.; Kim, C.J.; Chun, J.; Koh, Y.H.; Lee, S.H.; Hyun, J.W.; Cha, C.Y.; Kook, Y.H. (2004). Phylogenetic analysis of the genera Streptomyces and Kitasatospora based on partial RNA polymerase $\beta$-subunit gene (rpoB) sequences. Int. J. Syst. Evol. Microbiol., 54, 593-598.

18. Kumar, S.; Tamura, K.; Nei, M. (2004). MEGA 3: Integrated software for molecular evolutionary genetics analysis and sequence alignment. Briefings in Bioinform., 5, 150-163.

19. Kuster, E.; Williams, S.T. (1964). Selection of media for isolation of estreptomycetes. Nature, 202, 928-929.

20. Lazarovitz, G.; Nowak, J. (1997). Rhizobacterium for improvement of plant growth and establishment. Hortscience, 32, 188-192.

21. Levine, M. (1954). An introduction to laboratory technique in bacteriology. Mac Millan Press, New York, USA.

22. Macagnan, D.; Romeiro, R.S.; Souza, J.T.; Pomella, A.W.V. (2006). Isolation of actinomycetes and endospore-forming bacteria from the cacao pod surface and their antagonistic activity against the witches' broom and black pod pathogens. Phytoparasitica, 34, 122-132.

23. Melo, I.S.; Azevedo, J.L. (1998). Ecologia microbiana. Embrapa CNPMA, Jaguariúna, SP.

24. Pereira, J.C. (2000). Interações entre as populações de actinomicetos e outros organismos na rizosfera. Embrapa Agrobiologia, Documentos, 118, Seropédica. $15 \mathrm{p}$.

25. Poter, J.N.; Wilhelm, J.J.; Tresner, H.D. (1960). Method for the preferential isolation of actinomycetes from soils. Appl. Microbiol., 8, 174-178.

26. Rehner, S.A.; Buckley, E.P. (2003). Isolation and characterization of microsatellite loci from the entomopathogenic fungus Beauveria bassiana (Ascomycota: Hypocreales). Mol. Ecol. Notes, 3, 409411.

27. Renwick, H.; Campbell, R.; Coe, S. (1991). Assessment of in vivo screening systems for potencial biocontrol agents of Gaeumannomyces graminis. Plant Pathol., 40, 524-532.

28. Rice, R.A.; Greenberg, R. (2000). Cacao cultivation and the conservation of biological diversity. Ambio, 29, 167-173.

29. Sambrook, J.; Russel, D.W. (2001). Molecular Cloning: a Laboratory Manual. 3rd ed. Cold Spring Harbor, New York, USA.

30. Souza, J.T.; Pomella, A.W.V.; Bowers, J.H.; Pirovani, C.P.; Loguercio, L.L.; Hebbar, P.K. (2006). Genetic and biological diversity of Trichoderma stromaticum, a mycoparasite of the witches'broom pathogen. Phytopathology, 96, 61-67. 
31. Thompson, J.D.; Higgins, D.G.; Gibson, T.J. (1994). CLUSTAL W: impoving the sensitivity of progressive multiple alignment through sequence weighting, position-specific gap penalties and weight matrix choice. Nucleic Acids Res., 22, 4673-4680.

32. Tuite, J. (1969). Plant pathological methods: Fungi and Bacteria. Burgess Publishing Company, Minneapolis, USA.

33. Ueda, K.; Seki, T.; Kudo, T.; Yoshida, T.; Kataoka, M. (1999). Two distinct mechanisms cause heterogeneity of 16S rRNA. J. Bacteriol., $181,78-82$
34. Vessey, J.K. (2003). Plant growth promoting rhizobacteria as biofertilizers. Plant and Soil, 255, 571-586.

35. Woese, C.R. (1987). Bacterial evolution. Microbiol. Rev., 51, 221271.

36. Wong, P.T.W.; Baker, R. (1984). Suppression of wheat take-all and Ophiobolus patch by fluorescent pseudomonads from a Fusariumsuppressive soil. Soil Biol. Biochem., 16, 397-403. 